\title{
A Chemical and Morphological Study of Cassava Peel: A Potential Waste as Coagulant Aid
}

\author{
Syazwani Mohd-Asharuddin ${ }^{1}$, Norzila Othman ${ }^{1,{ }^{*}}$, Nur Shaylinda Mohd Zin ${ }^{1}$ and Husnul \\ Azan Tajarudin ${ }^{2}$ \\ ${ }^{1}$ Faculty of Civil and Environmental Engineering, Universiti Tun Hussein Onn Malaysia, 64200 Batu \\ Pahat, Johor, Malaysia \\ ${ }^{2}$ School of Industrial Technology, Universiti Sains Malaysia, 11800 Penang, Malaysia
}

\begin{abstract}
This study investigates the chemical and morphological characteristics of cassava peel (CP) biomass as a potential coagulant aid for turbidity, heavy metals and microbial removal. FE-SEM micrograph shown the surface of the $\mathrm{CP}$ samples was covered with smooth and globular in shaped of bound starch granules. FTIR spectra demonstrated that carboxyl and hydroxyl groups were present in abundance. Whereas analysis by XRF spectrometry indicated the CP samples contain $\mathrm{Fe}_{2} \mathrm{O}_{3}$ and $\mathrm{Al}_{2} \mathrm{O}_{3}$ which might contribute to its coagulation ability. The features of $\mathrm{CP}$ obtained from this study promotes the feasibility of CP to be further developed and studied to produce effective coagulant aid as sustainable alternative to reduce the usage of chemical coagulants.
\end{abstract}

\section{Introduction}

The production of potable water from most raw water sources usually involves the process called coagulation and flocculation. This process plays a major role in surface water treatment by reducing turbidity, algae, colour, organic compound, clay particles as well as removing microbial content in the water which results in minimizing the risk of waterborne diseases [1].

Aluminium salts, ferric salts and synthetic polymers are the most common coagulant used in water treatment worldwide. These coagulants are often expensive and many developing countries can hardly afford the costs of imported chemicals for water and waste water treatment. Besides, many researches have raised concern regarding the health effect related to Alzheimer disease caused by residual aluminium ions in the treated waters [2]. Meanwhile, some synthetic organic polymers such as acrylamide are regarded to neurotoxicity and strong carcinogenic effect [1].

For these reasons, alternative approach has been taken to produce novel coagulants with comparable coagulation capability from natural materials that are renewable, abundantly

\footnotetext{
* Corresponding author: norzila@uthm.edu.my
} 
available and relatively cost effective. Natural polymer coagulants such as chitosan, Moringa oleifera seeds, cactus mucilage and plant tannins are mainly composed of polysaccharides and proteins. These biopolymers shows promising potential to be a good choice of water coagulant not only due to their chemical composition but also they are usually available locally at low price and biodegradable $[1,3]$.

In view of the difference in coagulation capacity of various coagulants as well as considering techno-economic constrain, cassava peel $(\mathrm{CP})$ that is regionally available industrial waste is studied to evaluate it suitability to be selected as coagulant aid for water treatment system. A large amount of CP waste is generated annually by small and medium scale industries. This has led to a new strategy of complete utilization of raw materials so that there will be little or no residue left that could pose pollution problems. Conversion of this industrial by-product into coagulant and adsorption material for water treatment will not only enhance their market value but also reducing waste generated by the producer.

Cassava peels typically have higher concentration of cyanogenic glucosides than the pulp which this characteristic makes the peel unsuitable as animal feed [4]. However it is considered safe to use this agricultural waste as an alternative adsorbent since $\mathrm{CP}$ also contains a cyanide detoxification enzyme (cyanoalanine synthase) which sufficiently fast to maintain cyanide at safe concentration [5]. A study also reported that the CP contains sugars in the form of polysaccharides such as starch and holocellulose. Pectin, cellulose and amino acids containing abundant of carboxyl, hydroxyl and amino groups which has significant capabilities for metals binding from aqueous solution as well as flocculating agent $[6,7]$.

Hence, this paper aims to investigate the characteristics of CP waste as an early study in developing an alternative coagulant aid for turbidity, heavy metals and microbial removal. The surface morphological study and chemical composition analysis were performed on three different sample of CP namely CP1 (whole peel waste consist of periderm, cortex and flesh), CP2 (cortex only) and CP3 (flesh only). The cross sectional of cassava tuber is shown in Fig. 1.

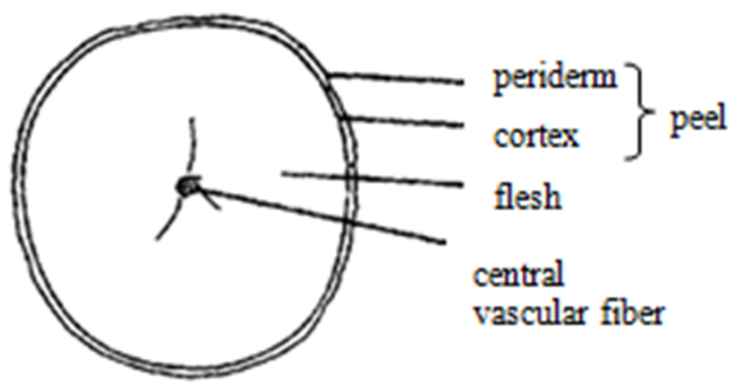

Fig. 1. Cross sectional of cassava tuber [8]

\section{Materials and methods}

\subsection{Preparation of biomaterial}

CP was collected as waste from Kilang Kerepek Ahmad Shah, Parit Raja Darat in Johor state, Malaysia. The raw CP was further processed to separate the sample into three type of sample consist of CP1 (periderm, cortex and flesh), CP2 (cortex only) and CP3 (flesh only). Then the $\mathrm{CP}$ samples were washed with tap water repeatedly to get rid of surface 
impurities. Then the peels were soaked in distilled water for further clean up at least for 24 hours followed by oven drying at $60^{\circ} \mathrm{C}$ for 24 hours to substantially remove its moisture content. The dried peels were then ground to fine powder using domestic blender and sieved to obtain desirable particle size of $<150 \mu \mathrm{m}[9,10]$. Final products were kept in air tight plastic container for further analysis.

\subsection{Field Emission Scanning Electron Microscopy (FE-SEM)}

This analysis was conducted to determine the surface morphology of the CP samples. Analysis was conducted at Microelectronics and Nanotechnology - Shamsuddin Research Centre (MINT-SRC), UTHM. The samples were mounted on the copper stub using an adhesive carbon tape. Then the samples were sputtered with platinum for 120 seconds at 30 $\mathrm{mA}$ under high vacuum until they were completely covered and ready to be used for the microscopic analysis [9]. The FE-SEM micrograph were observed using JEOL JSM-7600F Field Emission Scanning Electron Microscope (USA).

\subsection{Fourier Transform Infrared (FTIR) spectroscopy}

FTIR spectroscopy was done to identify surface functional group of native CP samples and performed using Perkin Elmer Spectrum 100 [9]. The adsorption bands were recorded at characteristics wave numbers between $600 \mathrm{~cm}^{-1}$ and $4,000 \mathrm{~cm}^{-1}$.

\subsection{X-Ray Fluoresence (XRF) spectrometry}

All CP samples were also subjected to XRF analysis to determine the elemental composition of the samples using Bruker AXS S4 Pioneer XRF spectrometer [9]. Prior to analysis, $8.0 \mathrm{~g}$ of pulverized samples were mixed homogeneously with $2.0 \mathrm{~g}$ of binder wax and compressed into pellet using PE-MAN Manual Hydraulic Press.

\section{Results and discussions}

\subsection{Field Emission Scanning Electron Microscopy (FE-SEM)}

The surface morphologies of the CP samples are depicted in Fig. 2-4. Based on the SEM micrographs at 500x magnification, it was observed that the CPs surface feature non-porous and heterogeneous characteristics. Similar observations were reported by other studies on SEM analysis on Cassava peel [9-11]. Smooth and globular in shape of bound starch granules were observed to mostly cover overall surface of CP1 and appeared to be in cluster on CP3 sample. While free unbound starch granules were observed in CP2. CP1 sample consist of the whole CP waste composed of the periderm, cortex and flesh layer which might be the reason of numerous appearance of starch granules on its surface.

Cassava tuberous roots are composed of a peel which contain about $10-20 \%$ of the tuberous root. The cork layer (periderm) covers $0.5-2.0 \%$ of the total tuberous root weight while the fleshy edible portion make up about $80-90 \%$ of the tuberous root. The roots are mainly consist of digestible carbohydrates and stored in starch granules. Cassava starch granules are composed of amylose (20\%) and amylopectin (80\%) [12]. A study on nutritional status of Cassava peel by Aderemi and Nworgu [13] showed that the protein content of the peels was $5.35 \%$, cellulose and hemicellulose contents were $5.40 \%$ and $21.65 \%$ respectively. 
Abdul-Aziz et. al [7] studied the sago starch as coagulant aid for heavy metals and turbidity removal. The research suggests that sago starch enhances the removal of positively charged heavy metals through charge neutralization mechanism. The starch attracts positively charged metals; destabilize the metals which cause them to agglomerate than precipitate.

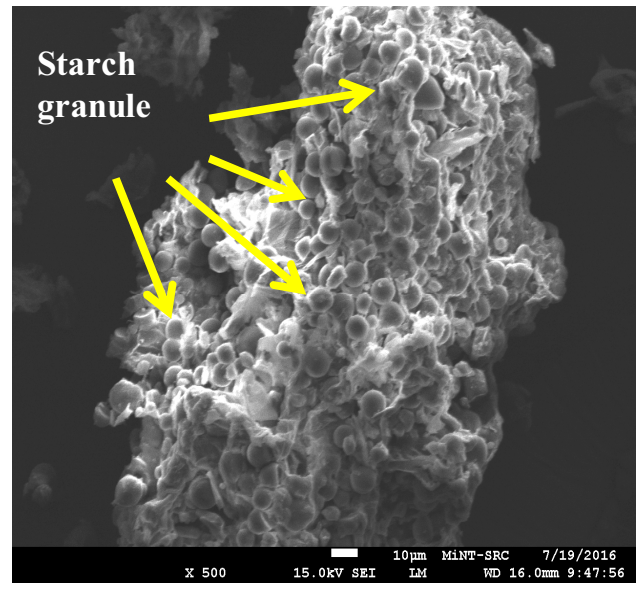

Fig. 2. FE-SEM micrograph of CP1

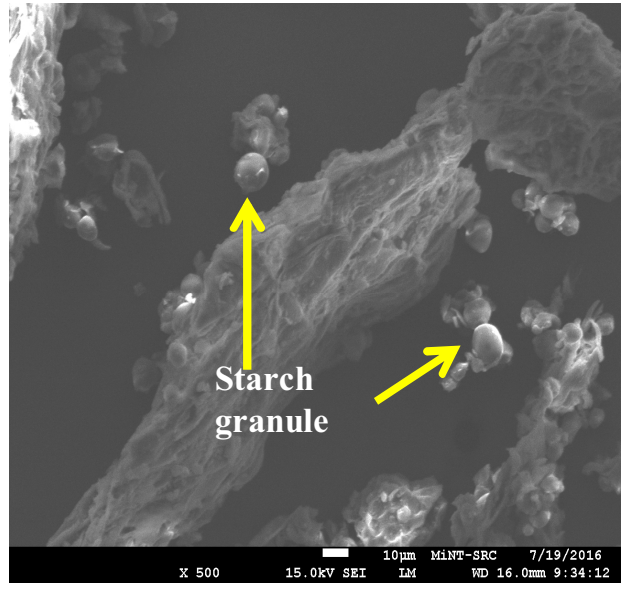

Fig. 3. FE-SEM micrograph of CP2

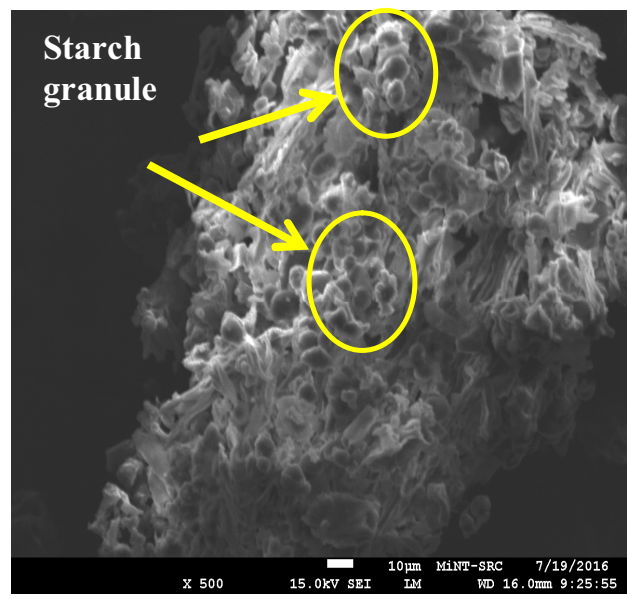

Fig. 4. FE-SEM micrograph of $\mathrm{CP} 3$

\subsection{Fourier Transform Infrared (FTIR) spectroscopy}

A comparison between the FTIR spectra of sample CP1, CP2 and CP3 is shown in Fig. 5. Peaks appearing in the FTIR spectra were assigned to various chemical groups and bonds in accordance with their respective wavenumbers $\left(\mathrm{cm}^{-1}\right)$.

The broad band observed between $3500-3200 \mathrm{~cm}^{-1}$ may be assigned to $\mathrm{O}-\mathrm{H}$ groups of free hydroxyl groups and bonded $\mathrm{O}-\mathrm{H}$ group in polymeric compounds such as alcohols, phenols and carboxylic acids presented in pectin, cellulose and lignin on the CPs. These bioactive components have been found to have antimicrobial properties [14]. The peak at 
wavenumber between $3000-2850 \mathrm{~cm}^{-1}$ may indicate the stretch of symmetric or asymmetric $\mathrm{CH}, \mathrm{CH}_{2}$, of aliphatic acids. Furthermore, the characteristic peak appeared between $1750-1680 \mathrm{~cm}^{-1}$ are demonstrating the stretching vibration of $\mathrm{C}=\mathrm{O}$ bond of carboxyl groups. Whereas the peaks observed between ${ }^{`} 1375-1300 \mathrm{~cm}^{-1}$ may reflect the stretching vibration of ionic carboxylic groups of pectin. While the deep peaks between $1300-1000 \mathrm{~cm}^{-1}$ indicate the $\mathrm{C}-\mathrm{O}$ stretching of $-\mathrm{COOH}$. The results were in agreement with FTIR analysis done onto Cucumis melo peels [15], mango peels [16] and citrus peels [17] as shown in Table 1.

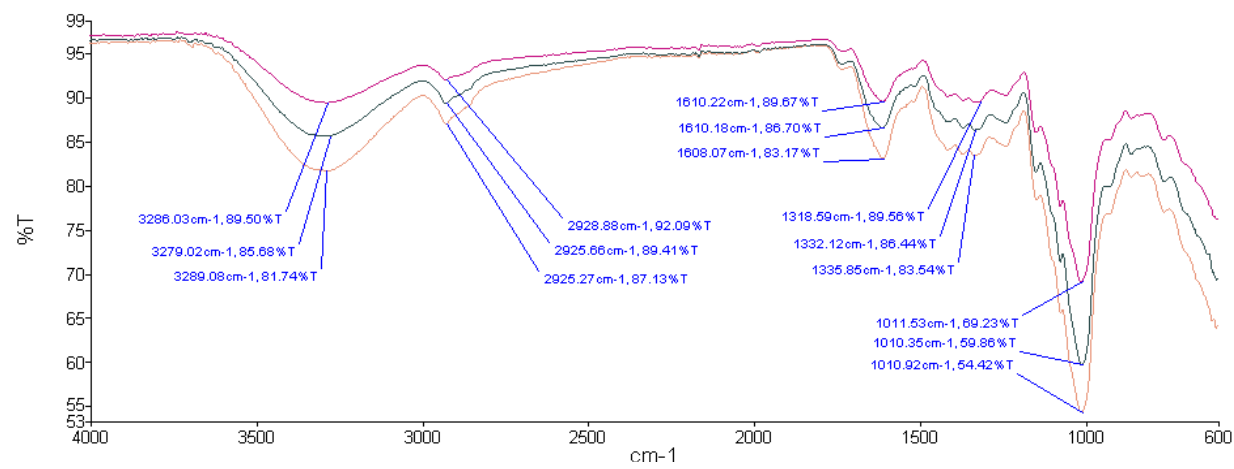

Fig. 5. FTIR spectra of $\mathrm{CP} 1, \mathrm{CP} 2$ and $\mathrm{CP} 3$

Table. 1. Functional groups identified by FTIR analysis

\begin{tabular}{|c|c|c|}
\hline $\begin{array}{l}\text { Agricultural } \\
\text { Waste } \\
\text { material }\end{array}$ & $\begin{array}{l}\text { Wavelength } \\
\text { Range }\left(\mathrm{cm}^{-}\right. \\
\left.{ }_{1}\right)\end{array}$ & Identified groups \\
\hline \multirow[t]{5}{*}{$\begin{array}{l}\text { Cassava peel } \\
\text { [this study] }\end{array}$} & $3500-3200$ & $\begin{array}{l}\text { O-H groups of free hydroxyl groups and bonded O-H in } \\
\text { polymeric compounds such as alcohol, phenols and } \\
\text { carboxylic acids }\end{array}$ \\
\hline & $3000-2850$ & $\begin{array}{c}\text { Symmetric or assymetric stretching of } \mathrm{CH}, \mathrm{CH} 2 \text { of } \\
\text { aliphatic acids }\end{array}$ \\
\hline & $1750-1680$ & Stretching vibration of $\mathrm{C}=\mathrm{O}$ bond of carboxyl groups \\
\hline & $1375-1300$ & Stretching vibration of ionic carboxylic groups \\
\hline & $1300-1000$ & $\mathrm{C}-\mathrm{O}$ stretching of $\mathrm{COOH}$ \\
\hline \multirow{5}{*}{$\begin{array}{l}\text { Cucumis } \\
\text { melo rind } \\
\quad[15]\end{array}$} & $3500-3200$ & $\begin{array}{l}\text { Bonded hydroxyl groups } \\
(-\mathrm{OH}) \text { and }(-\mathrm{NH}) \text { groups }\end{array}$ \\
\hline & $3000-2850$ & $\mathrm{C}-\mathrm{H}$ stretching, $-\mathrm{CH},-\mathrm{CH}_{2},-\mathrm{CH}_{3}$ \\
\hline & $1750-1680$ & $\mathrm{C}=\mathrm{O}$ carbonyl groups \\
\hline & $1640-1500$ & Carboxylate and carboxyl groups \\
\hline & $1300-1000$ & $-\mathrm{C}-\mathrm{O}$ or $-\mathrm{C}-\mathrm{N}$ bonds \\
\hline \multirow[t]{4}{*}{$\begin{array}{c}\text { Mango peel } \\
{[16]}\end{array}$} & $3500-3200$ & $\begin{array}{l}\text { Bonded hydroxyl groups } \\
(-\mathrm{OH}) \text { and }(-\mathrm{NH}) \text { groups }\end{array}$ \\
\hline & $3000-2850$ & $\mathrm{C}-\mathrm{H}$ stretching, $-\mathrm{CH},-\mathrm{CH}_{2},-\mathrm{CH}_{3}$ \\
\hline & $1750-1680$ & $\mathrm{C}=\mathrm{O}$ carbonyl groups \\
\hline & $1300-1000$ & $-\mathrm{C}-\mathrm{O}$ or $-\mathrm{C}-\mathrm{N}$ bonds \\
\hline \multirow{3}{*}{$\begin{array}{l}\text { Citrus peel } \\
{[17]}\end{array}$} & $3000-2850$ & C-H stretching, $-\mathrm{CH},-\mathrm{CH}_{2},-\mathrm{CH}_{3}$ \\
\hline & $1750-1680$ & $\mathrm{C}=\mathrm{O}$ carbonyl groups \\
\hline & $1640-1500$ & Carboxylate and carboxyl groups \\
\hline
\end{tabular}


Since cassava peel is principally made up of lignin and cellulose, it is well demonstrated from the FTIR spectra of each samples that carboxyl and hydroxyl groups were present in abundance especially in CP1 sample. These groups that constituted in biopolymers may function as proton donors; hence deprononated hydroxyl and carboxyl groups may be involved in the formation of alum-starch complex. The insoluble alum-starch salt may initially forms micro flocs (coagulation) which gradually grow to become macro flocs (flocculation). Over time, the macro flocs get settled and improve the water clarity [18].

Awang and Abdul-Aziz [19] suggest that carboxyl $(\mathrm{C}=\mathrm{O})$, hydroxyl $(\mathrm{O}-\mathrm{H})$ and amino or amide $\left(-\mathrm{NH}_{2}\right)$ groups as well as hydrogen bonding, which were the preferred groups for the flocculation process. The deprotonated carboxyl $(-\mathrm{C}=\mathrm{O}-)$ groups also might serves as ion bridge or binding sites for divalent metal cations $\left(\mathrm{Ca}^{2+}, \mathrm{Mg}^{2+}\right.$, etc. $)$ at the particle surface of wastewater to induce the coagulation activity.

Another research on the feasibility of $\mathrm{CP}$ to remove $\mathrm{Cu}(\mathrm{II})$ and $\mathrm{Ni}(\mathrm{II})$ indicates that the presence of of hydroxyl, carboxyl and carboxylate group contribute to the removal of the metals up to $90 \%$ [20]. The inclusion of hydroxyl group in CP on metal binding also reported by Kokasih et. al [5]. Jorgetto et. al [21] suggested that the oxygen on each hydroxyl group acts as a strong Lewis base because of the presence of its vacant double electrons, and this hydroxyl group undergoes a complex coordination with metal $\mathrm{Cu}$ (II) which is electron deficient.

\subsection{X-Ray Fluorescent (XRF) Spectrometry}

$\mathrm{XRF}$ analysis results are presented in Table 2. The elements present in the $\mathrm{CP}$ that gave it the coagulant properties are $\mathrm{Al}_{2} \mathrm{O}_{3}$ and $\mathrm{Fe}_{2} \mathrm{O}_{3}$. Both elements are expected to give the $\mathrm{CP}$ the ability to aid the coagulation process via precipitation of the particles in the raw water.

Standard alum consisted of 17-18 wt $\% \mathrm{Al}_{2} \mathrm{O}_{3}$ and 0.4-0.7 wt $\% \mathrm{Fe}_{2} \mathrm{O}_{3}$. Furthermore, the presence of $\mathrm{SiO}_{2}$ and $\mathrm{CaO}$ in $\mathrm{CP}$ might help in the addition of weight and size to particles in the raw water as in the case of activated silicate as a flocculation aid [22].

Moreover, $\mathrm{SiO}_{2}$ was also found in the CP. Same observation was reported in a study of rice husk characterization [23] and watermelon rind [24]. The study proposed that element that may be responsible for sorption are carbon and silica. Rao et al. [25] suggested that when the presence of Si-OH bonds would also act as cation exchange centers. This could be due to the substitution of metal ions at the site produces net negative charge which enables adsorption of cations.

Table 2. Elemental composition of cassava peel

\begin{tabular}{|c|c|c|c|}
\hline \multirow{2}{*}{ Formula } & \multicolumn{3}{|c|}{ Weight (\%) } \\
\cline { 2 - 4 } & $\mathrm{CP} 1$ & $\mathrm{CP} 2$ & $\mathrm{CP} 3$ \\
\hline $\mathrm{C}$ & 0.10 & 0.10 & 0.10 \\
\hline $\mathrm{K}_{2} \mathrm{O}$ & 5.48 & 6.18 & 5.83 \\
\hline $\mathrm{CaO}$ & 4.20 & 3.90 & 3.48 \\
\hline $\mathrm{Fe}_{2} \mathrm{O}_{3}$ & 1.54 & 0.33 & 0.41 \\
\hline $\mathrm{SiO}_{2}$ & 0.87 & 0.23 & 0.40 \\
\hline $\mathrm{SO}_{3}$ & 0.87 & 0.94 & 0.94 \\
\hline $\mathrm{Al}_{2} \mathrm{O}_{3}$ & 0.74 & - & 0.26 \\
\hline $\mathrm{P}_{2} \mathrm{O}_{5}$ & - & - & 0.42 \\
\hline
\end{tabular}




\section{Conclusions}

The characterization of CP samples which were accomplished through the analysis of FESEM, FTIR and XRF show the potential of CP1 sample which composed of the whole cassava peel waste comprises of the periderm, cortex and flesh to be developed as coagulant aid. The presence of starch granules, functional groups such as hydroxyl, carboxyl and amines as well as $\mathrm{Al}_{2} \mathrm{O}_{3}$ and $\mathrm{Fe}_{2} \mathrm{O}_{3}$ are important properties which accredited to the coagulating agents. Modification and optimization studies will be conducted in the future to further evaluate the performance of $\mathrm{CP}$ as coagulant aid for turbidity, heavy metals and microbial removal.

This paper was partly sponsored by the Centre for Graduate Studies UTHM and Fundamental Research Grant Scheme (FRGS Vot. 1575) supported by Ministry of Higher Education (MOHE).

\section{References}

[1] S. Vara, Screening and evaluation of innate coagulants for water treatment: A sustainable approach, Int. J. of Energy and Environmental Engineering, 3, 1-11, (2012)

[2] S.Y. Choy, K.M. Nagendra-Prasad, T.Y. Wu, M.E. Raghunandan, R.N. Ramanan, Utilization of plant-based natural coagulants as future alternatives towards sustainable water clarification, J. of Environmental Science, 26, 2178-2189, (2014)

[3] B. Ramavandi, Treatment of water turbidity and bacteria by using a coagulant extracted from Plantago ovate, Water Resource Industry, 6, 36-50, (2014)

[4] J. Kongkiattikajorn, B. Sornvoraweat, Comparative Study of Bioethanol Production from Cassava Peels by Monoculture and Co-Culture of Yeast, Kasetsart Journal, 45, 268-274, (2011)

[5] A.N. Kosasih, J. Febrianto, J. Sunarso, Y.H. Ju, N. Indraswati, S. Ismadji, Sequestering of $\mathrm{Cu}$ (II) from aqueous solution using cassava peel (Manihot esculenta), Journal of Hazardous Materials, 180, 366-374, (2010)

[6] G. Crini, Non-conventional low-cost adsorbents for dye removal: A review, Bioresource Technology, 97, 1061-1085. (2006)

[7] A.A. Hamidi, A. Mohd-Nordin, M.D.M. Abdul, R. Sujatha, M.I. Mohd-Koflly, A. Mohd-Harmizi, Study on the anionic natural coagulant for heavy metals and turbidity removal in water at ph 7.5 and alum concentration $25 \mathrm{mg} / 1$ - laboratory scale, Indian Journal of Engineering and Material Sciences, 7, 195-199, (2000)

[8] Food and Agriculture Organization of the United Nations (FAO). Rome, Italy. (1998)

[9] A. Kurniawan, A.N. Kosasih, J.Febrianto, Y.H. Ju, J. Sunarso, N. Indraswati, S. Ismadji, Evaluation of cassava peel waste as lowcost biosorbent for Ni-sorption: Equilibrium, kinetics, thermodynamics and mechanism, Chemical Engineering Journal, 172, 158-166, (2011)

[10]N. Zayadi, N. Othman., R. Hamdan, A potential waste to be selected as media for metal and nutrient removal, IOP Conference Series: Material Science and Engineering, 136(1), 012051, (2016)

[11]I.R.M. Benesi, Characterization of Malawian cassava germplasm for diversity, starch extraction and its native and modified properties. University of The Free State, Bloemfontein, South Africa. PhD. Thesis. (2005)

[12]I.R.M., Benesi, Genotype x Environment interaction effects on native cassava starch quality and potential for starch use in the commercial sector, African Crop Science J., 12, 205-216, (2004) 
[13]F.A. Aderemi, F.C. Nworgu, Nutritional status of cassava peels and root sieviate biodegraded with Aspergillus niger, American-Eurasian J. of Agriculture and Environmental Science, 2, 308-311, (2007)

[14]R.U. Maheswari, V. EuginAmala, Analyzing and Determining the Activity of Antimicrobial, Functional Group and Phytochemicals of Cymbopogon citratus using Well Diffusion, FT-IR and HPLC, Int. J. of Science and Research, 4, 138-141, (2015)

[15]N. Othman, S. Mohd-Asharuddin, Cucumis melo rind as biosorbent to remove Fe(II) and Mn(II) from synthetic groundwater solution, Advanced Materials Research, 795, 266-271, (2013)

[16]M. Iqbal, A. Saeed, S.I. Zafar, FTIR spectrophotometry, kinetics and adsorption isotherms modeling, ion exchange, and EDX analysis for understanding the mechanism of $\mathrm{Cd}^{2+}$ and $\mathrm{Pb}^{2+}$ removal by mango peel waste, Journal of Hazardous Materials, 164, 161-171, (2009)

[17] S. Schiewer, S. Patil, Modeling the effect of $\mathrm{pH}$ on biosorption of heavy metals by citrus peels, J. of Hazardous Materials, 157, 8-17, (2008)

[18]O.N. Abiola, Appraisal of cassava starch as coagulant aid in the alum coagulation of congo red from aqua system, Int. J. of Environmental Pollution and Solutions, 2, 47$58,(2014)$

[19] N.A. Awang, H. Abdul-Aziz, Hibiscus rosa-sinensis leaf extract as coagulant aid in leachate treatment, Applied Water Science, 2, 293-298, (2012)

[20]K.N. Awokoya, O.J. Owoade, B.A. Moronkola, B.K. Oguntade, A.A. Ibikunle, O.C. Atewolara-Odule, S.A. Ogundare, Morphological characteristics of cassava peel and its effect on the adsorption of heavy metal ions from aqueous media, J. of Multidisciplinary Engineering Science and Technology, 3, 5342-5348, (2016)

[21] A.D.O. Jorgetto, A.C.P, da-Silva, B.C.R.C. Barbosa, M.A. Utrera, and G.R. de-Castro, Cassava root husks as a sorbent material for the uptake and pre-concentration of cadmium(II) from aqueous media, Orbital: The Electronic J. of Chemistry, 5, 206-212, (2013)

[22]I. Muhammad-Misau, A.W. Abdulkarim-Yusuf, Characterization of water melon seed used as water treatment coagulant, Journal of Advanced Studies in Agricultural, Biological and Environmental Sciences, 3, 22-29, (2016)

[23] S. Noor-Syuhadah, H. Rohasliney, Rice husk as biosorbent: A Review, Health and the Environmental J., 3, 1-7, (2012)

[24]N.Othman, S.Y Kueh, M-F-H Azizul Rahman, R, Hamdan,R. Watermelon rind: a potential adsorbent for zinc removal, Applied mechanics and material, 680, 146-149, (2014)

[25] K.S. Rao, M. Mohapatra, S. Anand, P. Venkateswarlu, Review on cadmium removal from aqueous solutions, Int. J. of Engineering, Science and Technology, 2, 81-103, (2010) 